\title{
Mapping of pastoral corridors: practices and politics in eastern Senegal
}

\author{
Erin Kitchell ${ }^{1 *}$, Matthew D Turner ${ }^{1}$ and John G McPeak ${ }^{2}$
}

\begin{abstract}
The delineation and protection of transhumance corridors are increasingly seen as critical to maintaining livestock mobility in agropastoral areas of West Africa by allowing passage through areas of increasing cropping pressure. Understanding the local politics surrounding the mapping and protection of transhumance corridors is important for policy formulation. This study reports the findings of group meetings in nine local districts (communautés rurales) in eastern Senegal about recently mapped corridors. The focus of our observations include local perceptions of 1) the benefits and costs of corridors, 2) the effect of the recognition of corridors on competing land uses (particularly farming), 3) the need for and means to recognize and protect corridors, and 4) the appropriate level of authority to recognize and protect corridors. Our findings show significant geographical variation within the study area as to the perceived benefits and costs of corridors, with a major distinction between groups who view the function of corridors as protecting local farms from livestock passing through and those that understand corridors as critical for facilitating access to pastures. Given the significant overlap among multiple formal and informal poles of authority, the politics surrounding corridor delineation and protection are shaped less by the perceived costs to competing land uses than by contestation over the authority that designation and protection would require. Policy implications of findings for land use planning around corridors are discussed.
\end{abstract}

Keywords: Transhumance corridors; Land use planning; Mapping; Local politics; Formalization

\section{Background}

The need to promote and facilitate livestock mobility in semi-arid West Africa has not only been recognized by social and biophysical scientists (e.g. Ellis and Swift 1988; Niamir-Fuller 1999; Scoones 1994) but is also increasingly recognized by national governments in the region (Bonnet and Hérault 2011; Dongmo et al. 2012; Touré 2004; Wabnitz 2006). This recognition, in the form of broad statements in support of mobility and the rights of pastoral peoples, has unfortunately not translated into an increase or even the maintenance of livestock mobility (Fernandez-Gimenez and Le Febre 2006; Galvin 2009; Niamir-Fuller 1999). Pastoral mobility is shaped not only by tenure rights but by a whole host of factors including livestock wealth, labour availability, herding contracts, social insecurity, and social networks (De Bruijn and Van Djik 1995; Galvin 2009; Niamir-Fuller 1999; Turner et al.

\footnotetext{
* Correspondence: ekitchell@wisc.edu

'Department of Geography, 160 Science Hall, University of Wisconsin-Madison, 550 N Park St, Madison, WI 53706, USA Full list of author information is available at the end of the article
}

2014). Nonetheless, regional movements of livestock do require, at a minimum, the ability to move through agropastoral areas (feeding and watering livestock along the way) on a seasonal basis. Livestock in the region have historically moved seasonally along a north-south bioclimatic gradient (12 to $17^{\circ}$ north latitude). As a result, most of the region's livestock are located at the northern end of this gradient during the rainy season and the southern half of the gradient during the dry season. These seasonal movements, called transhumance, allow pastoralists to make use of predictable variations in pasture quality and availability. Mobility thereby optimizes use of a resource base that varies in space and time, with demonstrated benefits to livestock productivity and rangelands (Diallo 1978; Niamir-Fuller 1999; Penning de Vries and Djitèye 1982; Wagenaar et al. 1986). Corridors play a vital function in areas of mixed land use, particularly in the middle latitudes $\left(13.5^{\circ}\right.$ to $15^{\circ}$ north) where mobility is increasingly constrained due to land use competition with crop agriculture. By providing points of passage, corridors help maintain access to dispersed pastoral resources in 
the face of cropping pressure. They are thus central to maintaining the complementarity and integrity of pastoral resource systems.

A major limitation of current policy and development efforts to promote livestock mobility is the abstract embrace of livestock mobility. Just as early French geographers often mapped transhumance movements with broad arrows covering tens to hundreds of kilometres (e.g. Benoit 1979; Beauvilain 1977; Gallais 1975), ${ }^{a}$ there has been limited attention to the materiality of transhumance corridors at the national level - leaving the work of the recognition and designation of transhumance corridors to local jurisdictions. As rural peoples in agropastoral West Africa recognize, livestock corridors are physical paths of 5 to $25 \mathrm{~m}$ in width worn by repeated livestock passage. Important features of these corridors are pastoral encampment points, often near water, where calves and milking cows are separated from each other and from which livestock disperse to graze. The health of a corridor system is often less about the presence of a path of sufficient width to allow livestock to move between points $\mathrm{A}$ and $\mathrm{B}$ and more about the quality of pasture and water accessible from each resting point. A decline in such accessibility at locations along the corridor can erode the health of the livestock that depend on the corridor and increase the potential for social conflict between transhumance herders and local farmers (Brottem 2013; Niamir-Fuller 1999; Painter et al. 1994; Thébaud and Batterbury 2001; Turner et al. 2014).

In the context of decentralization, limited capacities of central governments, and limited understanding by government authorities of transhumance corridor networks, decisions about livestock corridors, if made at all, are made at the local level (Brottem 2013; Kitchell 2013). Given the fact that these regional corridor networks extend well beyond local jurisdictions, decision-making at this level lacks the administrative coordination required to maintain uninterrupted pathways; unless there is strong pastoral organization at the local level (often lacking), key pastoral resources (paths, encampments, water points) are likely to be compromised due to the common combination of bias of local authorities toward agricultural interests and insider-outsider politics (Brottem 2013; Moritz 2010; Niamir-Fuller 1999). There are multiple interests surrounding the location, recognition, and use of transhumance corridors working at different spatial and social organizational scales. The livestock are owned not only by pastoralists themselves but by farmers, merchants, and government officials living far from the corridor stretch in question (Habou and Danguioua 1991; Turner 2009). As such, these corridors have a public good character requiring some state involvement at broader administrative levels to represent extra-local interests.

\section{Study area}

Livestock husbandry in eastern Senegal has historically been dominated by seasonal movements around the Senegal River Valley (Fuuta Toro) with dispersal north into Mauritania and south into the Ferlo (Figure 1) during the rainy/flood seasons (June to November) and return to the floodplain during the dry season (December to May) (Ba 1986; Santoir 1983; Schmitz 1986). Expansion of irrigated cultivation, operation of the Manantali Dam (built in 1988), and recurrent drought have drastically reduced floodplain pastures (Schmitz 1993; Santoir 1983). This has increased the importance of more classic patterns of transhumance. Along the north-south axis, herds in the West African region will generally move north during the rainy season and south during the dry season. The latitudes to the north or south reached by transhumance herders vary based on the latitude of their home base and the level of mobility to which they are committed. Herds with bases in eastern Senegal may move up to several hundreds of kilometres north of the Senegal River Valley (16.5 to $17^{\circ}$ north latitude) and as far south as Kédougou in southeastern Senegal and Kéniéba in Mali $\left(12^{\circ}\right.$ to $12.5^{\circ}$ north latitude). Levels of mobility vary significantly among herds with some herds managed in semi-sedentary fashion (moving within a 40-km radius during the year) and others travelling across the full latitudinal range described above.

As elsewhere in the Sudano-Sahelian zone (Bassett and Turner 2007; Bernardet 1999; Blench 1994; Diop et al. 2012; Dongmo et al. 2012; Tonah 2006), there are reports over the past two decades of a southerly extension of transhumance corridors and an increase in the amount of time spent in the south with an increasing fraction of transhumance livestock remaining late in the dry season to catch the earlier rains to the south before moving north (Diop et al. 2012). A more recent feature of this trend has been the increased movement of livestock during the dry season toward the southeast into Mali (Kayes Region). These shifts in the timing of movements have an effect on the presence of the livestock in the more heavily cultivated areas in the middle latitudes (Figure 1).

The region's population is composed of multiple ethnic groups (Fulani or Toukouleur, Soninke, Maures, Wolof, Serer, and Bambara). All ethnicities own livestock but the Fulani and Maures are seen as livestock specialists. In the northern portion of the study area (Figure 1), cultivation pressure is very high along the historic floodplain of the Senegal River but drops off significantly moving south in the western portion of the study area and west in the eastern portion (as the Senegal River curves south and the Faleme tributary forms the border with Mali). Given the long-standing importance of livestock husbandry, customary organization of pastoralists has historically been important with particular Fulani clans acting as 


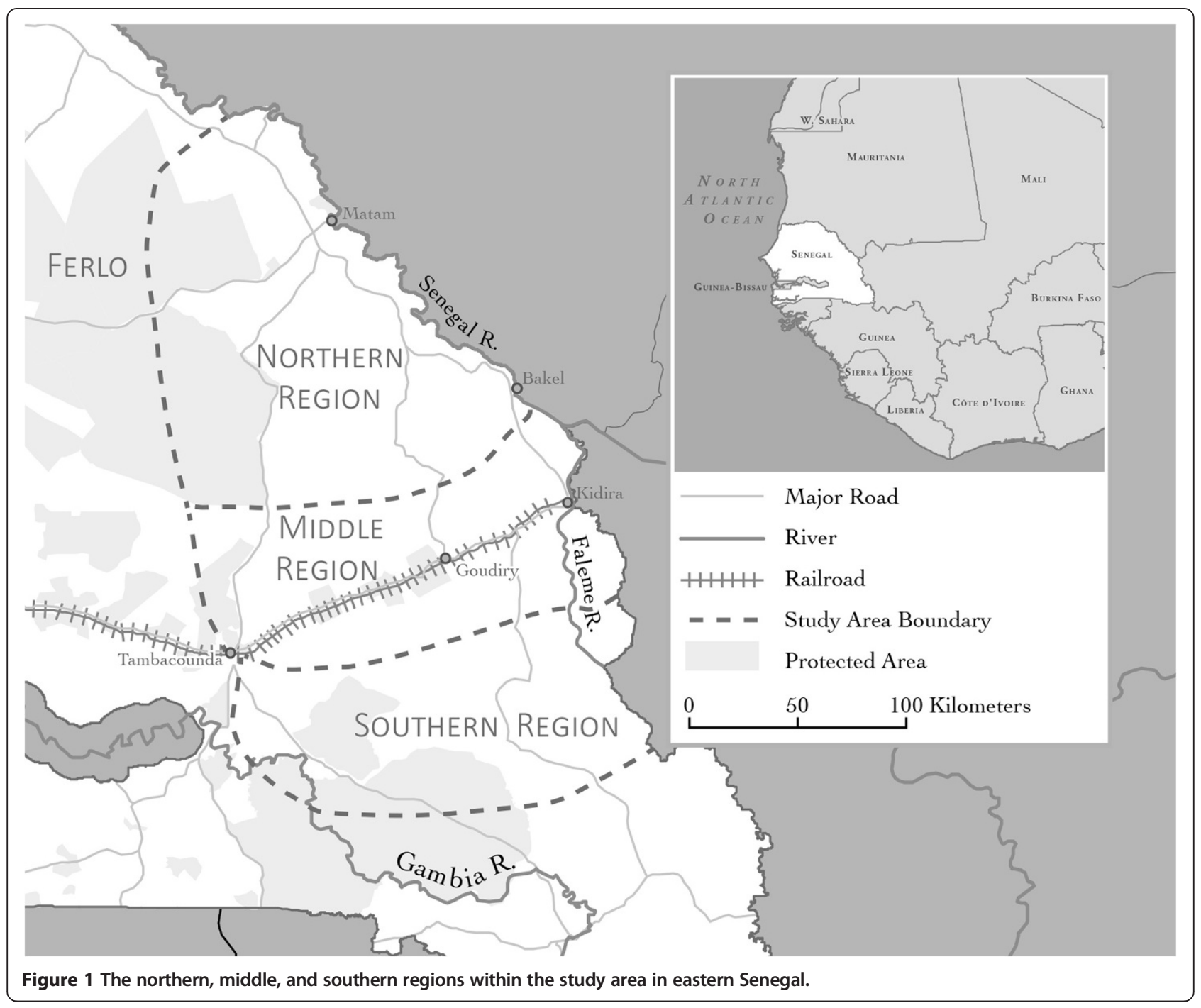

hosts at particular encampments and water points particularly in the Ferlo (Figure 1). Moreover, the Livestock Ministry of the Senegalese government has invested in the drilling of boreholes in the southern portion of the area and the establishment of pastoral associations to manage these (Juul 2001; Wane et al. 2009). These associations have supplanted customary organization in many parts of the north. In general, there is a broad acceptance of and identification with livestock husbandry both by residents and government agents in this part of the study area. In particular, there is a shared understanding that livestock, except for milch cows, need to move away from densely cultivated areas during the growing season.

Moving south into the middle portion of the study area (Figure 1), cultivation pressure increases, ethnic composition diversifies (greater presence of Wolof, Serer, and Manding groups), and the history and coherence of customary pastoral organization is more limited than to the north. This is the area where contemporary tensions between farming and herding groups run highest (higher land use competition) and the political influence of pastoral groups is relatively low. While the presence of transhumant livestock in the area is not new, its level of government-sponsored and customary organization is much lower than in the north. The government ministries that are most active in this area are concerned primarily with agriculture and forestry.

The southern portion of the study area (Figure 1) has historically had low population densities and has only recently experienced an increase in livestock presence and cultivation pressure (Diop et al. 2012). Still, cultivation pressure remains low in the area and a higher proportion of its area is under some sort of government protection (Figure 1). Given the limited historical presence of people in the area, it can be seen as a frontier zone. Customary pastoral organization is low with most livestock in the area 
present seasonally and managed by transhumant herders. Government presence is most felt through the activities and policies of Eaux et Forêts, the forestry agency, which generally has a negative posture toward livestock husbandry (Benjaminsen 1997).

\section{Institutional and administrative governance}

The history of decentralization of natural resource management in the study zone has important implications for efforts to formalize recognition of corridors. Government administration in Senegal is subdivided into four administrative levels. At the top of the administrative hierarchy, regions are governed by the Conseil Regional, an elected body. Each region is subdivided into departments, which in turn are divided into arrondissements. Both departments and arrondissements are purely administrative entities with no independent political bodies. They are respectively headed by préfets and sous-préfets, appointed by the central government. Finally, at the lowest level, each arrondissement is composed of communes (cities) and communautés rurales (rural districts composed of multiple villages, hereafter $\mathrm{CR}$ ) administered by directly elected local governments. There are currently more than 370 CRs in Senegal. New CRs have been established over time through successive subdivisions within the state territorial administration; the most recently established CRs in the study region (e.g. Bala, one of our study sites) were created in 2009.

The current institutional structure is the result of an administrative decentralization process, initiated in 1972 and reformed in 1996. A 1972 reform of territorial administration (Loi 72-25) established communes and CRs with legal and financial autonomy. However, communes and CRs continued to be under the budgetary control of the sous-préfet until the transfer of administrative management to the president of rural councils and city mayors in 1990. The decentralization reform of 1996 (Loi 96-06) further empowered local elected councils by transferring a number of administrative responsibilities to the commune and CR levels (notably land use planning and natural resource management). However, the devolution of administrative authority to local levels was not accompanied by an equivalent transfer of necessary financial resources (O'Bannon 2006). In addition, ultimate authority over resource management remains ambiguous due to the continued power of sector agencies in decision-making over natural resources. Further, by establishing a new pole of authority in an already complex institutional landscape, the establishment of CR councils complicates rather than resolves institutional pluralism at the local level. Devolution of powers to new artificially created units failed to build from existing tenure institutions, bringing the CR's administrative authority into competition with the customary authority of pre-existing local management institutions (Hesse et al. 2000). Institutional changes under decentralization have thus altered the allocation of powers and responsibilities for resource management and reshaped the legitimacy of particular forms of resource governance. As these resulting shifts in power are contested, processes of decentralization become enmeshed in the production and reproduction of hierarchy at the local level (Gray 2006; Poteete and Ribot 2011).

\section{Methods}

The mapping of transhumance corridors could provide information needed to support the development of comanagement systems as well as to communicate information to local authorities about the placement of a local corridor within a broader corridor system. This paper reports on an ongoing research project focused on developing and using this information to support management decisions in eastern Senegal. The general data collection procedure followed by this project involves three basic steps:

1. Meetings with pastoral and other community leaders to identify major corridors on which their livestock depend during the year;

2. Collection of GPS coordinates and basic information for these corridors as well as for associated encampments and water points with the help of pastoralist guides;

3. Presentation and discussion of provisional maps of these corridor features with representatives of major interest groups at the level of each CR traversed by mapped corridors. A major focus of these discussions is the recognition of these corridor features at the local level.

This paper focuses on our experience with the third step of this procedure which has been completed in nine CRs in eastern Senegal. We orient our observations to address the following four questions concerning local resource users' varied perspectives on corridors:

1. What are the benefits and costs of corridors and do they require protection?

2. How does the mapping of corridors and encampments affect competing land uses (particularly farming)?

3. How should corridors and encampments be recognized and protected?

4. Under what authority should corridors and encampments be recognized and protected?

These questions lie at the heart of the politics that surround land use planning and locally brokered agreements to support livestock mobility. At a more abstract level, what is the purpose of corridors in peoples' minds and do these 
purposes warrant particular forms of protection against competing land uses? If corridors need to be protected, how should they be protected and under whose authority? Finally, what additional issues arise with respect to competing claims to land when particular locations of corridors and encampments are presented? After addressing these questions, the paper concludes with a discussion of the policy implications of these findings.

\section{Corridor mapping project}

The authors are involved in a research project in eastern Senegal to develop methods to map, characterize the status of, and widely disseminate information about transhumance corridors. ${ }^{b}$ The spatial organization of transhumance corridors reflects the nutritional needs of livestock and herders as they move long distances. To ensure that livestock are adequately fed, herds will generally move only a portion of the day along corridors, stopping at encampment points from which livestock disperse to graze after unweaned animals are separated from mothers. After grazing, mothers are milked before being reunited with their calves. Generally, encampment points are located at or within short distances of water sources (ponds, wells, rivers, etc.) with choice of encampment points determined not only by the quality and quantity of forage but also by the quality and accessibility of water.

For this project, major corridors used by livestock in the region are initially identified in group meetings of pastoralists, livestock agents, and local administrators at the level of the arrondissement. In these meetings, corridors are simply described by listing the succession of encampments used by pastoralists when moving along the corridor in a particular direction. More detailed information was collected by following each of these paths with a herder guide. GPS coordinates are collected for the corridors, encampment points, and water points used by livestock at encampment points. In addition, encampments are characterized as to cultivation pressure, customary control, exclusionary rights, and pasture quality. Water points used by livestock are characterized as to type, seasonal availability, water quality, and cropped field presence. The project so far has mapped and characterized around 500 encampments and 600 water points located along $3,000 \mathrm{~km}$ of transhumance corridors within the study area (Figure 2).

The final step of the data gathering process is the sharing of provisional maps with representatives from each local district (CR) crossed by mapped transhumance corridors. Corridors mapped so far in the project cross 29 CRs (Figure 2). Of these, meetings have been held in nine CRs (Figure 2). After orienting participants to the map, the meetings are focused on the following:

1. verifying information gathered with the herder guide (names and placement of encampments and water points as well as information gathered to characterize these as described above);

2. characterizing the cultivation pressure experienced along corridor sections lying between encampments;

3. characterizing the degree to which there is customary and governmental recognition of corridors and encampments within the CR;

4. characterizing the nature of protections of corridors and encampments by customary or governmental authorities against agricultural pressure.

The outcome of these meetings is the verification of the information gathered from herder guides as well as the collection of additional information about the vulnerability of corridors and encampments to agriculture pressure and informal and formal recognition and protection of these corridor sites. This information will be incorporated into an on-line digital map available to interested parties with effective access to the internet (generally government ministries and nongovernmental organizations) and flat maps at different spatial scales provided to local and regional governments as well as pastoral and farming associations. The goal of such information dissemination is for all parties involved in rural land use planning to have accurate information about the existing corridor network and its vulnerabilities.

This paper reports on observations made during nine CR meetings in May and June of 2013 in which provisional maps were presented to informants to verify locations and discuss the degree to which corridors and encampments are locally recognized (as described above). These observations were made not only to address the research questions as outlined above but also to evaluate the process and make necessary adjustments to our approach. CRs were chosen from the set of 29 districts based on the completeness of GPS data collection and in order to span the administrative subdivisions and latitudinal range of the study area.

Qualitative observations were used to address the four research questions described above. While a participant in the meetings, the first author of this paper served as both an observer and interviewer with research assistants taking the lead at running the meeting and recording survey information. When discussions arose relevant to our research questions, questions were posed by the first author to clarify people's understandings and positions. Groups ranged in size from five to ten people; participants included representatives of the $\mathrm{CR}$ council and a mix of residents who self-identified as farmers or herders. ${ }^{\mathrm{c}}$ Although many producers both farm and own livestock, they tend to identify with a particular socio-professional identity that is shaped by the relative importance of cropping and herding for household income and social history. While we hereafter use the terms 'farmers' and 'herders', it is important to note that in many areas farmers also own livestock and 


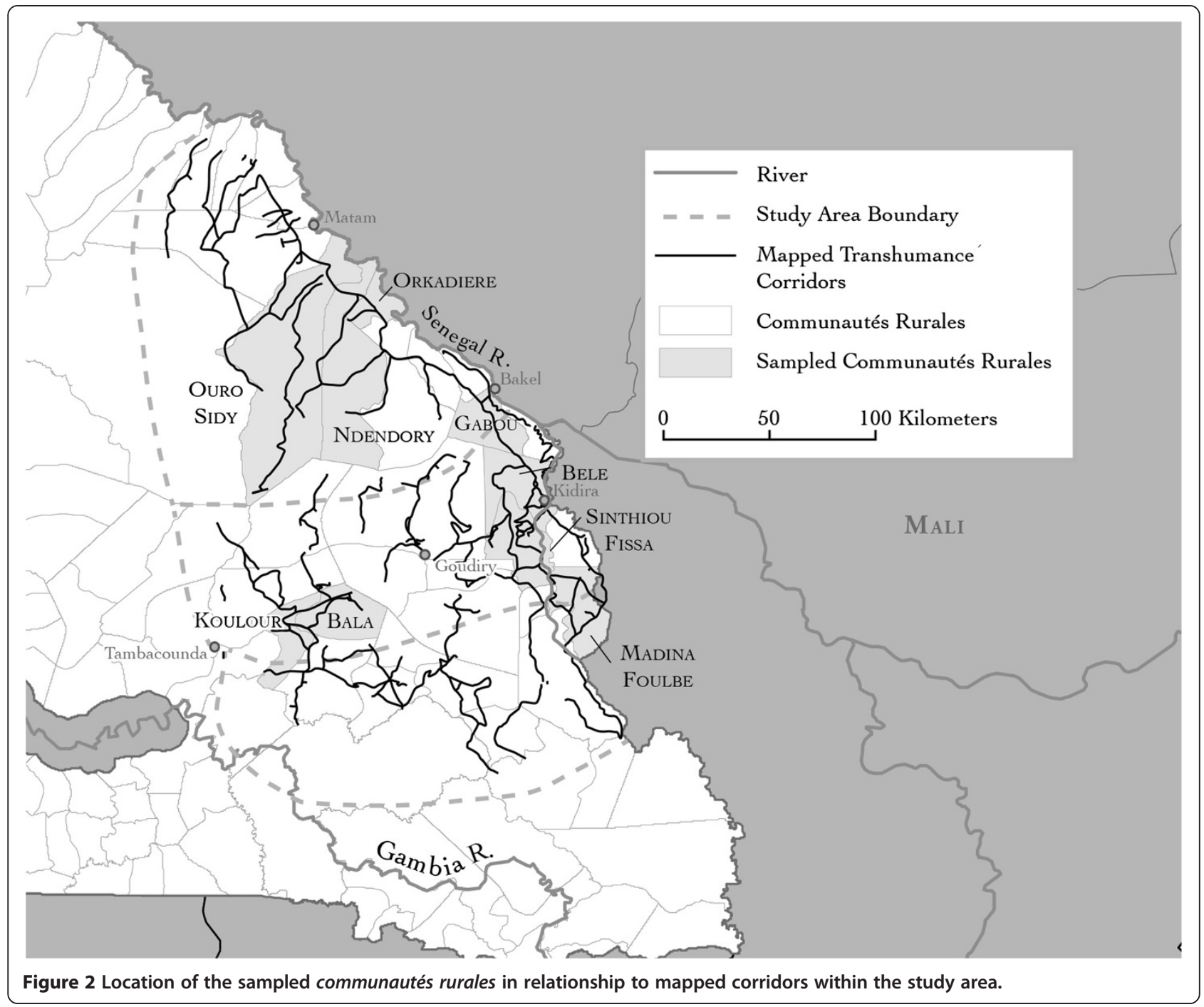

may use corridors. After the initial description of our project, its methods, and goals for the meeting, reactions from participants often gravitated to perspectives on the benefits and costs of corridors and whether they should be recognized or protected (questions 1 and 3). Verification of the names and locations of corridors and encampments as outlined on provisional maps often led to discussions about the degree to which these pastoral sites were seen as competing against alternative land uses (question 2). Through a series of questions about local recognition, participants were asked about political and social contestation over corridor segments and resting points, formal and informal recognition by the CR, and the degree to which each segment and resting point were taken into account in decisions to permit or prohibit cropping and payments for crop damage. These questions also led to discussions related to the politics of fixing corridors (question 2) as well as the issue of authority to recognize and protect corridors in particular ways (questions 3 and 4).
The pre-defined set of survey questions thus led to unstructured discussions of the meaning of recognition, the roles played by different actors and institutions, and the factors affecting local decision-making about specific cases of encroachment and crop damage. Conversations were guided by open-ended questions by the first author to clarify divergent perspectives among participants in a given group as well as to explore variation among CRs.

\section{Results}

Perspectives on the purpose and benefits of corridors

In all nine CRs in which meetings were held, corridors enjoyed some level of recognition by residents and district officials. Degree of recognition was assessed in terms of informal acceptance of corridor use, overt contestation of corridor sections by the CR or a given social group, and whether the corridor was taken into account in CR decision-making about land allocation, land use planning, and conflict resolution. Most often, recognition 
was informal, consisting of the acknowledgement that corridors existed and were subject to some degree of customary regulation. Corridors were largely accepted as a long-standing feature of local production systems that play an important role in facilitating the accommodation of cropping and livestock husbandry. ${ }^{\mathrm{d}}$ While accommodation between different production systems was central to participants' views of corridors, four distinct functions, variably stressed by different social groups, can be identified: to avoid conflict, reduce crop damage, ensure access, and prevent agricultural encroachment.

Participants most frequently spoke of the purpose of corridors as landscape features to manage or prevent conflict. People usually referred to conflict between farmers and herders resulting from crop damage, but corridors were also sometimes discussed in terms of their potential role in mitigating tensions between herding groups. Farmers, herders, and agropastoralists from across the three zones all emphasized this as one of the primary purposes of locally recognized corridors. Under prevailing conditions of overlapping land uses with multiple claimants holding different use rights, corridors provide a means of clarifying access and channelling livestock pressure through known routes. They also serve the function of pinpointing the local individual(s) responsible for managing transhumance movements by associating transhumant encampments with particular settlements where a host resides. Of course, the degree of responsibility and authority over management varies widely and extra-local herders may choose not to contact local hosts. Various actors interpret the role of corridors in reducing conflict in quite different ways; one perspective views corridors as a means to keep livestock away from fields, while another emphasizes the role of corridors in enabling access to a broader ensemble of pastoral resources. Not surprisingly, farmers often spoke of the regulation of corridors not only in terms of their geographic delimitation but also in terms of specifying the temporal dimensions of their use. This can be seen as an example of the degree to which corridors' perceived roles in managing conflict and preventing crop damage are sometimes interwoven. As will be discussed below, when corridors are used as a means to manage conflicts between competing land uses with a strong focus on crop damage, corridor delineation and regulation can become primarily a means of constraining rather than enhancing mobility.

While a range of social groups across the study sites stressed the management of conflict and crop damage as among the principle purposes of corridors, many herders also emphasized corridors as a means for ensuring positive rights of access. Local recognition of corridors was viewed as a validation of pastoral claims to particular paths and areas of pasture. In a basic sense, it represented a commitment to the persistence of an extensive livestock production system by allowing transit through agricultural areas. However, this clarification of a right of transit and access to pasture did not always extend to a sense that corridors also connoted protection against future cultivation. Herders perceived agricultural encroachment as a pressing problem for livestock production, but did not always view it as an infringement on established pastoral rights. Understandings of corridor recognition as serving a strong positive right to maintaining corridors and pasture sites free from cultivation were generally expressed in areas that either had politically active pastoral associations or that had recently been involved in processes of land use planning facilitated by outside agencies and focused on corridor protection. In discussions with participants, the political organization of pastoralists and education campaigns about legislation on mobility seemed to increase the likelihood that herders view corridors as inherently providing protection from future agricultural pressure. By providing a representative body, pastoral associations play an important role in articulating pastoral interests and enhancing their political clout.

\section{Politics surrounding the 'fixing' of corridors on provisional maps}

In preparing for meetings at the $\mathrm{CR}$, we expected the question of corridor and encampment placement on provisional maps to be highly sensitive. As a visual representation delineating current land use, maps of corridors could be interpreted as fixing boundaries around accepted social uses of resources. Surprisingly, discussions focusing specifically on corridor placement were much less contentious than anticipated. There were two principal reasons for this. First, corridors were often considered to already be relatively fixed in practice, particularly in zones with higher cropping pressure. As a result, the placement on the map was approached in a matter-of-fact manner; there was little implication that mapping corridors substantially altered shared understandings of boundaries. Second, the delineation of corridor location was not associated with strong commitments to protect corridors as a land use. In particular, recognition was not taken to mean consistent enforcement of prohibitions on cropping along corridors and near encampments and water points. In effect, residents did not immediately perceive corridor recognition as strengthening pastoral land rights.

A significant degree of consensus existed on areas understood to be important for transhumant herds, and the idea that the CR may recognize corridors and encampments as legitimate land uses was not perceived as immediately threatening to competing land uses. While the geographic siting of areas used by transhumant herds elicited little dispute, the politics surrounding questions of 
access within this schema came to dominate discussions. Related issues included the timing of access, how herders gain authorization for use, how penalties for crop damage are defined, social expectations of both residents and extra-local herders, and the regulation of related resources (tree browse in forests, water supplies at village wells and boreholes). It was when these issues become the focus of discussion that questions about competing land uses came to the fore. To the extent that corridor recognition was understood as an acknowledgement of long-used livestock paths, contention was diminished. However, the dimensions of access and the degree to which quality pasture and water points should carry restrictions against agricultural expansion generated much greater debate. In the context of corridor formalization, the extent to which these politics are explicitly addressed will depend on divergent conceptions of corridors as 1) points of transit out of an area or 2) as features of pastoral geographies with associated requirements for adequate access to forage and water.

In addition, in discussions of whether the provisional maps accurately reflected current practice, differential knowledge of the geographic realities of transhumance became evident, with important implications for the scale of organization of resource management. Residents from one area of the CR often had limited knowledge of livestock paths in another area. Participants from the same district also held divergent viewpoints of the importance of corridors depending on the characteristics of different locations within the $\mathrm{CR}$ (cropping pressure, density and duration of livestock presence). Further, of those present at meetings, $\mathrm{CR}$ officials tended to be the least knowledgeable about the geographic location of corridors. This reflects the importance of the village level in ongoing corridor management. Similarly, participants from a given CR were sometimes unaware of paths in their district that had been identified as important by residents of other CRs. There was little perception of corridor protection as a cross-boundary issue that required coordination with neighbouring districts. Reviewing the provisional maps in multiple CRs thus highlighted both a higher degree of resistance to protecting access to pasture around encampments than to the delineation of corridors themselves and low levels of coordination among local entities and across districts. These two issues represent critical obstacles that must be addressed in order to maintain the viability of a broader corridor system (Moutari and Girault 2013).

Perceptions of the need for formal recognition of corridors Whether or not special forms of protection, notably through the formal recognition of corridors by the CR, were viewed as necessary depended on several factors: 1 ) the degree to which customary systems of regulation and accommodation were perceived as still functioning,
2) social relations between user groups within a district, and 3) the level of land use pressure in the area. Thus, significant differences existed among groups in terms of the perceived need to formalize corridors and how the benefits associated with formalization were understood. Formal recognition and protection of corridors tended to be most frequently viewed as necessary in areas with high agricultural pressure and in areas where there was a more limited history of social interaction between transhumant herders and local residents.

Practices of accommodation between cropping and herding have a long history in the region. The historical integration of livestock paths into customary systems of land management was often referenced in discussions of decision-making about corridors, particularly in areas to the east and north of the railroad (Figure 1). The degree to which customary agreements were still functioning had an important effect on attitudes toward the need for formal protection. When customary systems were viewed as effectively managing land use and related disputes, residents saw intervention by local elected officials as unnecessary and sometimes as inappropriate. In Bala, it was stated that when arbitrating crop damage, the CR simply followed agreements made by elders several generations earlier, referred to by participants as 'village law'. Both residents and CR officials felt that the CR lacked the authority to infringe upon customary arrangements. In some cases, the precedence of customary arrangements protected mobility by restricting the ability of CR officials to alter existing land use agreements; however, since land use planning and allocation for cultivation take place at the CR level, its diminished role in regulating corridors could also indirectly promote agricultural encroachment.

In addition to the functioning of customary arrangements, the nature of social relations among user groups also influenced the perceived need for protection of corridors. This was particularly evident in the northern zone. Populated mainly by Fulani who share a socio-professional identity rooted in livestock ownership, corridors in this area were seen as an unquestioned aspect of local production systems. However, corridors were rarely viewed as a formal feature of land use planning nor did they receive protection at the CR level. On the one hand, widespread social acceptance of livestock paths created a stronger sense of a right to mobility than elsewhere, while on the other, the perception of corridors as part of the social fabric of local communities led to a reliance on mutual accommodation and reduced the perceived need to formalize protection at the district level. The intensity of conflict when crop damage did occur was reported to be relatively low. One participant explained that a shared socio-professional identity defused conflict, emphasizing 'we're all Fulbe'. In addition, participants in northern districts explicitly placed responsibility for preventing crop damage on both farmers and herders. Further, 
most farmers in this zone own a significant number of livestock and also make use of corridors. Unlike in other areas, conflict in the northern zone did not rise to the level of outright or latent social confrontation between different groups, but was instead expressed as isolated flare-ups between particular individuals. However, there is evidence that more persistent social divisions in attitudes toward livestock mobility may be developing, particularly in reference to irrigated areas along the river.

In areas where relationships between transhumant herders and residents were established enough to facilitate informal negotiation of access, perceptions that corridors required formal protection were weaker. This tended to be the case in localities where transhumant herders pass a significant portion of the year and return in successive years, leading to closer relationships among groups and diluting strict definitions of 'insider' and 'outsider'. In one case, a CR official referred to the herders who had been coming to his district regularly for more than 10 years as 'living there', noting that they spend more time annually in his district than in their home territories. In situations such as these, transhumant herders may even pay taxes and vote in local CR elections. These social dynamics existed in districts located at the southern end point of a corridor that had relatively extensive areas of pasture (e.g. Madina Foulbe).

This contrasted sharply with dynamics in transit zones located in the middle zone of the study area. Transhumant pastoralists spent much shorter periods of time in these areas and were likely to use different series of encampment sites in successive years. In addition, cropping pressure is higher in this zone and the timing of livestock movements results in higher numbers of livestock being present during the planting season. Residents of areas with higher land use pressure expressed greater interest and even a sense of urgency about the formalization of corridors and access rights. This dynamic was heightened in areas that had also experienced recent changes in the timing of livestock movements. Increased potential for crop damage resulted in corridors being perceived as a necessary means to avoid conflict. However, this conjunction of interests between farmers and herders emerged from very different understandings of the implications of defining corridors. In many CRs, the focus was on preventing conflict. Given the dominance of agricultural interests at the local and district levels, conflict prevention was often couched in terms of reducing crop damage by regulating and constraining the movement of livestock in and around fields.

For example, the CR of Koulour attempted to institute a management system in 2008 designed to control the location and timing of livestock movement. Each group of herders was required to present themselves to village chiefs, declare the number of days they would be spending in nearby encampments, and pay a user fee of 10,000 CFA francs to every village in which they stopped overnight. In addition, December 31 was set as the date of the earliest possible entry into the CR. While restrictions on livestock access were elaborated, little emphasis was placed on protecting corridors from agricultural encroachment. In this case, formalization of corridors clearly represented a broader claim to control and restrict the access of outside groups. However, the system quickly collapsed with outsider herders simply refusing to participate or abide by the new restrictions. As in this failed attempt to curtail crop damage, in most districts of the middle zone, a reciprocal commitment to maintain corridors to facilitate livestock movements into and through cropped areas was missing. This was evidenced by the very rare occurrence of prohibitions of cropping on corridors and near water points. Although land use pressure creates incentives on both sides to formalize protection of corridors, divergent perceptions of 'protection' can undermine consensus and may lead to mixed results in terms of enhancing livestock mobility.

\section{Divergent views of authority: institutional politics surrounding corridor protection}

As we have seen, a continuum exists in perceptions of whether or not corridors require special forms of protection beyond extant arrangements at the local level. However, of even greater importance for efforts to enhance mobility, divergent views of the appropriate authority for protecting corridors reveal a distinct institutional politics associated with formalizing corridors. A variety of institutions are involved formally and informally in the regulation of livestock movement. Relations among these various institutions are typified by both cooperation and contention over the right to manage resources. Building institutions to support livestock mobility is political not only because of the act of inscribing physical boundaries but also because recognition requires a negotiation among competing authorities. The levels at which farming and herding interests are represented differ. As representatives of local settlements, village chiefs and the CR are likely to favour cultivation interests. Herders lack formal representation in decision-making over land use in the districts outside their home territory, despite their extended presence locally and the regional importance of livestock production. Instead, herders exercise political authority through clan or family heads, pastoral associations, and by appealing to the regional livestock service (ministry). Across the study districts, there was considerable variation in the prominence of customary leaders, locally elected CR officials, state-sponsored pastoral associations, and sector agencies in decision-making about livestock mobility. In different local contexts, effective authority over livestock mobility is shaped by the shifting 
power of these institutions resulting from several factors, notably the level of political organization among pastoralists, village density, the prevalence of protected areas, and the history of livestock movements in the area. The allocation of responsibilities for protecting corridors within formalization processes has two implications. First, different institutions are likely to embody vested interests in a particular land use. Second, when understood as an issue of precedent among competing poles of authority, contestation over the specific issue of corridors becomes a symbol in broader social struggles for control over resources.

The roles played by various administrative bodies and informal institutions differed from one CR to the next. Nonetheless, some broad trends were apparent across districts. First, village chiefs are often the primary level at which questions of access are negotiated. This is the case not only due to their customary authority to allocate cropland and arbitrate conflict but also because of their geographic proximity to the resources in question. In some cases, this authority was delegated to village committees, of which the village chief or a representative of his choice was a member. In general, both farmers and herders viewed the village chief as a legitimate interlocutor. However, this does not mean that herders always inform them of their actions nor respect their decisions. Differing perceptions of the responsibilities of herders and the level of control exercised by village chiefs led to frustration on both sides. In particular, herders' unwillingness to make their presence in the area known to the village chief and to camp near villages was a growing source of tension between groups.

The CR is also widely acknowledged as an important source of authority over livestock mobility, particularly through upholding and legitimizing the decisions of village chiefs. In addition, CR officials played a central role in addressing conflicts that were unable to be successfully resolved among the two parties at the village level. They often determined whether or not the gendarmerie should become involved and formal judicial procedures initiated. Before the addition of the CR into Senegal's administrative structure, the arrondissement government was too far removed to impinge much on local affairs. Although the district government of the CR is much closer to the local level at which management questions arise and are resolved, it also has a limited enforcement capacity and continues to rely on village chiefs as the mechanism for implementing its decisions. A relationship of interdependence exists between the CR and village chiefs. Nonetheless, the relationship is also characterized by contestation and competing interests. The ambiguity between customary authority and the elected officials of the CR government is particularly strong in areas where new CRs had only recently been created (e.g. Bala established by decree in 2009). Residents' attitudes toward regulation by the $\mathrm{CR}$ were generally positive, but in the absence of outright conflict, its efficacy was considered low because of a limited ability to perform oversight. Some participants stated that formal recognition of corridors at the CR level made little difference because it had little effect on cultivation in practice and was frequently not taken into account when resolving crop damage disputes. The CR becomes more prominent in decisionmaking about livestock mobility when external bodies implement programming in the district explicitly targeting the issue. This is due to the preponderant focus within development projects on the district government as the main actor in local governance, though many projects also engage village chiefs or village committees.

Given the prominence of agricultural interests at the village and CR levels, the activity of pastoral associations is also important in the context of authority over corridors. Herders who participated in the meetings saw these associations as a means of redressing their political marginalization at the CR level. District officials themselves often view pastoral associations or committees as a necessary mechanism for regulating livestock movement. Following the failed attempt to initiate a formal system of regulating corridors in Koulour noted above, CR officials expressed interest in trying a similar scheme again, but this time with the involvement of a committee of herders from the Fouta. The inability of both village chiefs and the CR to enforce unilateral decisions about corridor use leads to their realization that it is necessary to implicate herders themselves in the elaboration and enforcement of rules. However, for this to occur, external herders need an organized form of local representation. In some areas, negotiations have happened with family heads or an informal leader chosen from among herders. Pastoral associations can serve as a counterpart to territorially based management institutions (village chiefs, the CR). Further, the rarity with which herders voiced claims to positive rights indicates the need to increase mobilization around the issue of land rights and pastoral tenure security; pastoral associations appeared to significantly increase awareness of existing rights.

Finally, the activities of sectoral agencies are implicated in the interactions between different institutions at the local level. As has been discussed elsewhere, ambiguity exists in the allocation responsibilities for land management between the CR and sectoral ministries (notably the forestry and livestock ministries) (Poteete and Ribot 2011; Ribot 2009). The tensions between them with respect to decision-making about land use can be exploited by residents and extra-local herders alike, with each party seeking intervention from the authority it perceives as most likely to support its own interests (what has been termed 'forum shopping', see Ribot and Peluso (2003)). Geographic 
differences in ministry activities are also important for shaping attitudes toward corridors ('Background' section above). The livestock ministry has historically focused its interventions on the northern zone and has been an important source of development financing there. In northern and eastern districts, it was invoked as playing a very active role in local resource management, both through the distribution of resources and infrastructure and through active intervention in processes of land use planning. Pastoral associations often targeted the livestock ministry and the regional livestock service as their primary ally in the state administration. In agropastoral zones just south of the Ferlo, this dynamic leads to tensions between the livestock ministry and residents; some residents in these areas viewed grazing permits (autorisations d'entrée) distributed by the regional livestock service as the state backing herders and forcing residents to deal with depredations associated with mobility (mainly cutting of trees). Permits were viewed as awarding outsiders rights which had not been properly negotiated with residents, thus infringing on their authority. Interestingly, however, villages were able to use noncompliance to increase local control by placing tighter restrictions on herders without the required papers.

In contrast, the prominence of protected areas and forestry agents in the southern zone has decidedly different effects. In these districts, the dialogue on transhumance and corridors is dominated by concerns about forest cutting. This has been exacerbated by a species shift in use of corridors from grazers to browsers and a new push to the southeast by corridor users. The forestry agency's perception of livestock herding as a source of forest degradation has contributed to shaping both local officials' and residents' attitudes toward corridors. Due to the low level of agricultural pressure in this zone, contention over livestock mobility centres not on crop damage but instead on the impacts on forest cover and health. In Medina Foulbe, comités de vigilance were established at the village level and charged with supervision of forest use. The emphasis was on reducing cutting of certain species including Acacia seyal, an important source of tree browse. Backed by the forestry service, this effort to enhance local control over resources collapsed when an altercation between one village committee and extra-local herders led to several committee members being jailed. The lack of formal legal status for the committees and the resultant ambiguity in their authority were noted as a significant obstacle to effective resource management.

Despite the tensions sparked between divergent socioprofessional groups, a study undertaken as part of the Project for Livestock Development in Senegal and the Casamance (PDESOC, a regional project under the direction of the livestock ministry) recommended the resurrection and reorganization of these committees as a primary means to achieving ongoing implementation and monitoring of corridor protection (Diop et al. 2013). Although this recommendation represents an attempt to enhance coordination among villages, the $\mathrm{CR}$, and relevant ministries, explicit attention to the politics that typify interactions among these administrative levels and development of means for the incorporation of herders in decision-making is required to build enduring institutions for managing mobility.

\section{Conclusion: implications for land use planning efforts}

Conflicts between farmers and herders are inherent to the mosaic of land use typical of Sudano-Sahelian West Africa. Local cases of conflict have historically been negotiated through complex, multi-stranded social relations that connect different user groups (Turner 1999; Turner 2006). However, the dominant focus on the village scale in land policy and development projects has historically privileged agricultural interests and discounted pastoralists, effectively resulting in enclosures (Marty 1993; Painter et al. 1994). Further, the local and regional administrations responsible for land use planning are dominated by agricultural constituencies in many areas. The 'paradox of pastoral tenure' has been described as providing both flexibility in resource use and security of access (Fernandez-Gimenez 2002; Moritz et. al. 2013). Although informal negotiation at local sites has considerable benefits in terms of flexibility, given the expansion of agriculture and the increasing political dominance and material control of certain zones by farming interests, it is inadequate for securing access to pastoral resources. Intervention of higher-level state authorities is necessary to protect the livelihood security of herders and ensure coordination with respect to transhumance corridors that cross multiple jurisdictions (Bassett 2009; Moutari and Girault 2013; van Driel 1997). The governance of pastoral mobility involves a multitude of institutions and actors operating at a variety of scales. Maintaining transhumance as a regional resource use system thus requires both some form of co-management and a proactive role for state authorities.

Scholars have raised concerns that the formalization of livestock corridors under state authority will result in a loss of flexibility for pastoralists due to the reliance on delimiting a fixed pastoral infrastructure and the reduced ability of local user groups to develop their own negotiated solutions (Dafinger and Pelican 2006; Mortiz et al. 2013). Although flexibility is an essential aspect of pastoral resource systems, the expansion of cropping in agropastoral areas necessitates a hybrid approach to management that embraces flexibility among pastoral groups but operates within negotiated, mutually acceptable boundaries that protect pastoral resources from agricultural encroachment. Recent research using spatial analysis has shown that the nature of resource variability (notably inter-annual variability in forage phenology 
and the existence of key forage patches) has seasonal regularities that are compatible with the territorial protection of movement corridors and key pastoral resources (Brottem et al. 2014). Within these regional corridor networks, flexibility can be maintained through flexible pastoral tenure arrangements to access forage and water for livestock. In fact, clear ownership rights to pasture and water among pastoralists in eastern Senegal are rare along our mapped transhumance corridors. Therefore, if corridor mapping is approached as part of an ongoing process of negotiated land use planning rather than as an end in itself, it can be an important step in enabling coordination across competing institutions.

Careful attention to the nature of institutional politics around corridors is necessary to facilitate this. Our analysis examined divergences in local perceptions of the function of corridors and the authorities involved in management in order to understand the politics of corridor protection. In the course of meetings, discussions inevitably focused less on the placement of corridors and more on corridor recognition. Debates about recognition were equally affected by questions about 1) what protections should be accorded and 2) who has the authority to recognize corridors. Depending on their understanding of the purpose of corridors, resource users hold two related but competing perspectives on corridor protection. The first is controloriented, emphasizing the prevention of crop damage and reduction of conflict; the second is access-oriented emphasizing corridors as a means to ensure access to pastures. While these can be complimentary, creating opportunities for negotiation between groups motivated by different ends, it is important to note that regulations on corridors are alternately used to claim access rights and to exclude certain users or uses. Without a clear understanding of the functions of corridors in pastoral mobility (i.e. requirements of water and pasture associated with stopping points along corridors), formalization can result in corridors acting as restrictive spaces for livestock. Maintaining the possibility of mobility in only this narrow sense will have a significantly negative effect on livestock production. Given the dominance of agricultural interests at the CR level in many districts, it is necessary to ensure that formalized recognition of corridors is coupled with protection of pastoral sites from competing land uses if livestock mobility is to be enhanced.

Moreover, in the context of overlapping institutions for resource management, authority over corridor recognition is highly contested. Variations in the relative authority of different institutions mean that the management of pastoral mobility is effectively in different institutional hands at different points along the corridor. Attempts to formally delineate and protect livestock corridors will inevitably be confronted by the institutional politics surrounding control over management. Greater coordination is required across administrative levels to effectively implement regulations protecting corridors. However, the development of possible solutions is hindered when debates about corridors become proxies for struggles over authority in resource management, with the dominant discourse favouring the interests of settled cultivators. Outside facilitators of land use planning processes should take a process-oriented approach that emphasizes institution building rather than the one-time production of a land use map; such an approach requires ongoing support and a longer time horizon. In particular, at the CR level, more training is needed on extant national policy as well as support in formulating, implementing, and maintaining land use agreements around mobility. Since villages are where implementation inevitably occurs, village-level authorities need to be included in planning processes in meaningful ways. Likewise, transhumant groups need to be represented in decision-making in order to enhance legitimacy and increase the durability of land use agreements. The ability to effectively involve herding groups is complicated by the timing of their presence and their level of internal organization. Informal institutions may offer an important starting point for defining shared norms among transhumant herders and CR residents. These include understandings of customary rights and responsibilities in which mutual obligations among user groups are emphasized. In some areas, close social relations between groups can facilitate negotiation. Finally, generating consensus on the application of rules protecting mobility is intertwined with the resolution of tangential problems. In particular, these include whether or not herders announce themselves to local bodies, establishment of social ties that might diminish incidences of aggression, acceptance of local rules on tree cutting, and reduction of livestock theft.

There is a fundamental disconnect between the scale at which corridors operate and the management institution of a village or CR. Corridors cross multiple CRs and even international borders, but the need for coordinated governance has yet to be integrated into the logic of decentralization and local management of natural resources. Ensuring that agricultural expansion does not have strong detrimental effects on livestock mobility requires regional scale, coordinated efforts that take into account both the materiality of corridors and the local institutional politics surrounding corridor protection.

\section{Endnotes}

${ }^{a}$ The older of these depictions most likely reflect the reality of the geography of livestock movements in the past since corridors are in part a creation of agricultural pressure. Without agricultural pressure, livestock paths are best described as movement zones composed of a series of intersecting, braided paths with the same orientation within a broad band of land. 
${ }^{\mathrm{b}}$ This geospatial information will not only assist in conflict management and land use planning but also be used by the research project to estimate the benefits and costs of alternative land uses where herding and cropping (especially irrigated cropping) co-exist.

${ }^{\mathrm{c}}$ Although corridors may have been identified by herding informants residing outside of the communauté rurale, local 'herders' as well as 'farmers' were generally quite familiar with these corridors and associated resting and water points with many, especially herders, using these for their own livestock.

${ }^{\mathrm{d}}$ Nonetheless, this customary function of corridors is complicated by changes in the intensity and timing of use. In particular, contention has increased around the international corridor that follows the river from Matam to areas south of Kidira as it has become more heavily travelled and the frequency of tree coppicing for browse has increased.

\section{Competing interests}

The authors declare that they have no competing interests.

\section{Authors' contributions}

EK collected and analysed the qualitative data from focus group meetings. EK wrote an initial draft of the 'Results' and 'Conclusions' sections, and MDT wrote an initial draft of the 'Introduction' and 'Methods' sections. MDT designed the overall corridor mapping study with the assistance of JM. MDT processed and analysed the geospatial data to produce the provisional maps used at focus group meetings. All authors were involved in editing and approved the final manuscript.

\section{Authors' information}

EK is a PhD student in geography at the University of Wisconsin-Madison focusing on the intersections between land use change, governance institutions, and climate change vulnerability in agropastoral communities in Senegal and Mali. MDT is a Professor in the Department of Geography whose research is concerned with environmental dynamics and the institutions and politics that surround resource management in Sahelian West Africa. JM is an Associate Professor in the Department of Public Administration and International Affairs at Syracuse University who works on the economics of pastoral systems and is the Principal Investigator of the project that conducted this research, La Gestion des Systèmes Fluviaux pour l'Avenir.

\section{Acknowledgements}

Mame Astou Diagne, Mouhamed Mandiang, Pathé Thiongane, and Mamadou Thioube contributed to this work as research assistants. This work was supported by the Bureau for Economic Growth, Agriculture and Trade of the United States Agency for International Development under the terms of grant no. EEM-A-00-10-00001. This grant is managed by the Feed the Future Innovation Lab for Collaborative Research on Adapting Livestock Systems to Climate Change. The opinions expressed herein are those of the authors and do not necessarily reflect the views of the United States Agency for International Development, the US Government, or the Feed the Future Innovation Lab.

\section{Author details \\ ${ }^{1}$ Department of Geography, 160 Science Hall, University of Wisconsin-Madison, 550 N Park St, Madison, WI 53706, USA. ${ }^{2}$ Maxwell School, Department of Public Administration and International Affairs, 333 Eggers Hall, Syracuse University, Syracuse, NY 13244-1020, USA.}

Received: 17 June 2014 Accepted: 9 September 2014

Published online: 08 October 2014

\section{References}

Ba, C. 1986. Les Peul du Senegal. Étude géographique. Dakar: Les nouvelles éditions africaines.
Bassett, TJ. 2009. Mobile pastoralism on the brink of land privatization in Northern Côte d'Ivoire. Geoforum 40: 756-766. doi:10.1016/j. geoforum.2009.04.005.

Bassett, TM, and MD Turner. 2007. Sudden shift or migratory drift? Fulbe herd movements to the Sudano-Guinean region of West Africa. Human Ecology 35: $33-49$.

Beauvilain, A. 1977. Les Peul du Dallol Bosso, Etudes Nigeriennes 42. Niamey, Niger: Institut de Recherche en Sciences Humaines.

Benjaminsen, TA. 1997. Natural resource management, paradigm shifts, and the decentralization reform in Mali. Human Ecology 25(1): 121-143.

Benoit, M. 1979. Le chemin des Peuls du Boobola: Contribution à l'écologie du pastoralisme en Afrique des savanes. Paris: O.R.S.T.O.M.

Bernardet, P. 1999. Peuls en mouvement, Peuls en conflits en moyenne et haute Côte d'Ivoire, de 1950 à 1990. In Figures peules, ed. R Botte, J Boutrais, and J Schmitz, 407-444. Paris: Karthala.

Blench, RM. 1994. The expansion and adaptation of Fulbe pastoralism to subhumid and humid conditions in Nigeria. Cahiers d'Etudes Africaines 133-135: 197-212.

Bonnet, B, and D Hérault. 2011. Gouvernance du foncier pastorale et changement climatique au Sahel. Revue des questions foncières (Land Tenure Journal) 2: 157-187.

Brottem, L. 2013. The place of the Fula: Intersections of political and environmental change in western Mali. Madison: University of Wisconsin.

Brottem, L, MD Turner, B Butt, and A Singh. 2014. Biophysical variability and pastoral rights to resources: West African transhumance revisited. Human Ecology 42: 351-365. doi:10.1007/s10745-014-9640-1.

Dafinger, A, and M Pelican. 2006. Sharing or Dividing the Land? Land Rights and Farmer-Herder relations in Burkina Faso and Northwest Cameroon. Canadian Journal of African Studies 40(1): 127-151.

De Bruijn, M, and H Van Djik. 1995. Arid ways: Cultural understandings of insecurity in Fulbe society, central Mali. Amsterdam: Thela Publishers.

Diallo, A. 1978. Transhumance: Comportement, nutrition et productivite d'un troupeau zebus de Diafarabé, Thèse. Bamako, Mali: Centre Pédagogique Supérieure.

Diop, AT, JD Cesaro, A Touré, A Ickowicz, and B Toutain. 2012. Évolution des transhumances. In Atlas des evolutions des systemes pastoraux au Sahel 1970-2012. SIPSA Report to FAO, ed. I Touré, A Ickowicz, A Wane, I Garba, and P Gerber, 14-15. Rome: Food and Agriculture Organization.

Diop, AT, A Mbengue, MJ Senghor, and M Diene. 2013. La gestion de la transhumance et la mise en place de cadre de concertation au niveau de I'arrondisement de Kenieba. Dakar: Projet de Developpement de l'Elevage au Senegal Orientale et en Casamance (PDESOC).

Dongmo, A-L, E Vall, MA Diallo, P Dugué, A Njoya, and J Lossouarn. 2012. Herding territories in Northern Cameroon and Western Burkina Faso: Spatial arrangements and herd management. Pastoralism: Research, Policy, and Practice 2: 26. doi:10.1186/2041-7136-2-26.

Ellis, JE, and DM Swift. 1988. Stability of African pastoral ecosystems: Alternate paradigms and implications for development. Journal of Range Management 41: 450-459.

Fernandez-Gimenez, ME. 2002. Spatial and Social Boundaries and the Paradox of Pastoral Land Tenure: A Case Study from Postsocialist Mongolia. Human Ecology 30(1): 49-78.

Fernandez-Gimenez, ME, and S Le Febre. 2006. Mobility in pastoral systems: Dynamic flux or downward trend? International Journal of Sustainable Development and World Ecology 13: 341-362.

Gallais, J. 1975. Paysans et pasteurs du Gourma. La condition sahélienne. Paris: CNRS.

Galvin, KA. 2009. Transitions: Pastoralists living with change. Annual Review of Anthropology 38: 185-198.

Gray, LC. 2006. Decentralization, land policy, and the politics of scale in Burkina Faso. In Globalization and new geographies of conservation, ed. K Zimmerer, 277-295. Chicago: University of Chicago Press.

Habou, A, and A Danguioua. 1991. Transfert du capital—betail au Niger (des pasteurs aux autres catégories socio-professionelles). Niamey, Niger: Secretariat Permanent du Comite National du Code Rural.

Hesse, C, P Trench, and Pippa. 2000. Decentralisation and institutional survival of the fittest in the Sahel: What hope for CPRM? London: IED.

Juul, K. 2001. Power, pastures, and politics: Boreholes and decentralization of local resources management in Northern Senegal. In Power, politics, and production in the West African Sahel, ed. T Benjaminsen and C Lund, 57-74. Stockholm: Elanders Gotab.

Kitchell, E. 2013. The social dimensions of livestock mobility: Climate risk, information networks, and resource governance in Central Senegal. Madison: 
University of Wisconsin-Madison. http://minds.wisconsin.edu/handle/1793/ 67937.

Marty, A. 1993. La gestion des terroirs et les éleveurs: Un outil d'exclusion ou de négociation? Revue Tiers Monde 34: 329-344.

Moritz, M. 2010. Understanding herder-farmer conflicts in West Africa: Outline of a processual approach. Human Organization 69(2): 138-148.

Moritz, M, LB Catherine, AK Drent, S Kari, A Mouhaman, and P Scholte. 2013. Rangeland governance in an open system: Protecting transhumance corridors in the far north region of Cameroon. Pastoralism: Research, Policy and Practice 3: 26. doi:10.1186/2041-7136-3-26.

Moutari, EM, and F Girault. 2013. Le corridor de transhumance au Sahel: Un archétype de territoire multisitué ? L'Espace Géographique 42: 306-323.

Niamir-Fuller, M. 1999. Managing mobility in African rangelands. London: Intermediate Technology Publications.

O'Bannon, B. 2006. Receiving an "empty envelope": Governance reforms and the management of farmer-herder conflict in Senegal. Canadian Journal of African Studies 40(1): 76-100.

Painter, T, J Sumberg, and T Price. 1994. Your terroir and my 'action space': Implications of differentiation, mobility and diversification for the approche terroir in Sahelian West Africa. Africa 64(4): 447-463.

Penning de Vries, FWT, and MA Djitèye. 1982. La productivite des paturages Saheliens: Une etude des soils, des vegetations et de l'exploitation de cette ressource naturelle. Wageningen, The Netherlands: Centre for Agricultural Publishing and Documentation.

Poteete, AR, and JC Ribot. 2011. Repetoires of domination: Decentralization as process in Botswana and Senegal. World Development 39(3): 439-449.

Ribot, J. 2009. Authority over forests: Empowerment and subordination in Senegal's democratic decentralization. Development and Change 40(1): 105-129.

Ribot, J, and NL Peluso. 2003. A theory of access. Rural Sociology 68(2): 153-181. doi:10.1111/j.1549-0831.2003.tb00133.

Santoir, C. 1983. Raison pastorale et politique de développement. Les Peuls Sénégalais face aux amenagements, Travaux et Documents de I'ORSTOM. No. 166. Paris: ORSTOM.

Schmitz, J. 1986. L'État géomètre: Les leydi des Peul du Fuuta Tooro (Sénégal) et du Maasina (Mali). Cahiers d'Etudes Africaines 26(3): 349-394.

Schmitz, J. 1993. Anthropologie des conflits fonciers et hydropolitique du fleuve Sénégal (1975-1991). Cahiers des Sciences Humaines 29(4): 591-623.

Scoones, I. 1994. Living with uncertainty. New directions in pastoral development in Africa. London: Intermediate Technology Publications Ltd.

Thébaud, B, and S Batterbury. 2001. Sahel pastoralists: Opportunism, struggle, conflict and negotiation. Global Environmental Change 11: 69-78.

Tonah, S. 2006. Migration and farmer-herder conflicts in Ghana's Volta Basin. Canadian Journal of African Studies 40(1): 162-178.

Touré, O. 2004. The impact of pastoral legislation on equitable and sustainable natural resource management in Guinea. London: International Institute for Environment and Development. Issue paper no. 126.

Turner, MD. 1999. The role of social networks, indefinite boundaries and political bargaining in maintaining the ecological and economic resiliency of the transhumance systems of Sudano-Sahelian West Africa. In Managing mobility in African rangelands: The legitimization of transhumance, ed. M NiamirFuller, 97-123. London: Intermediate Technology Publications.

Turner, MD. 2006. The Micropolitics of Common Property Management on the Maasina Floodplains of Central Mali. Canadian Journal of African Studies 40(1): 41-75.

Turner, MD. 2009. Capital on the move: The changing relation between livestock and labor in Mali, West Africa. Geoforum 40: 746-755.

Turner, MD, J McPeak, and AA Ayantunde. 2014. The role of livestock mobility in the livelihood strategies of rural peoples in semi-arid West Africa. Human Ecology 42(2): 231-247. doi:10.1007/s10745-013-9636-2.

van Driel, A. 1997. Relations entre agriculteurs et éleveurs: Cohabitation et problèmes majeurs. In Agriculteurs et éleveurs au Nord-Bénin, ed. L D De Haan, 127-148. Paris: Karthala.

Wabnitz, H-W. 2006. Le code pastoral de la République Islamique de la Mauritanie: Un exemple parfait de législation traditionnelle. In Les frontières de la question foncière: Enchassement social des droits et politiques publiques. Montepellier, France: Institut de Recherche pour le Développement
Wagenaar, KT, A Diallo, and AR Sayers. 1986. Productivity of Transhumant Fulani Cattle in the Inner Niger Delta of Mali. Addis Ababa: International Livestock Centre for Africa.

Wane, Abdrahmane, Véronique Ancey, and Basile Grosdidier. 2006. Les unités pastorales du Sahel sénégalais, outils de gestion de l'élevage et des espaces pastoraux. Projet durable ou projet de développement durable? Développement durable et territoires. Économie, géographie, politique, droit, sociologie Dossier 8.

doi:10.1186/s13570-014-0017-2

Cite this article as: Kitchell et al:: Mapping of pastoral corridors: practices and politics in eastern Senegal. Pastoralism: Research, Policy and Practice

2014 4:17.

\section{Submit your manuscript to a SpringerOpen ${ }^{\circ}$ journal and benefit from:}

- Convenient online submission

- Rigorous peer review

- Immediate publication on acceptance

- Open access: articles freely available online

- High visibility within the field

- Retaining the copyright to your article

Submit your next manuscript at $>$ springeropen.com 